\title{
On The Role Of Management Commitment In Export Performance: A Meta-Analysis
}

Hind El Makrini, ESDES - Université Catholique de Lyon, France

Anissa Chaibi, IPAG Business School, France

\begin{abstract}
Research on exporting frequently points the role of management commitment in the export performance of the firm. This article reviews the conceptual, methodological, and empirical insights gained from a systematic analysis of 65 studies conducted on this subject. Undoubtedly, this stream of research has enhanced understanding of the importance of management commitment in affecting exporting activities. However, conceptually, there is still a lack of integral theoretical framework. Methodologically, limitations are identified concerning sampling designs, fieldwork procedures, and analytical methods. Empirically, hypothesized associations between export commitment and export performance lead to conflicting findings. After a presentation of meta-analysis techniques used and articles compiled, our paper provides an original investigation of this issue by implementing three meta-analyses to examine the relationship between commitment to export and export performance. The meta-analysis, more relevant than simple literature surveys, generally leads to the conclusion that there is a significant positive relationship between export commitment and export performance. Moreover, our findings suggest directions for future research in the field.
\end{abstract}

Keywords: Meta-Analysis; Commitment To Export; Export Performance

\section{INTRODUCTION}

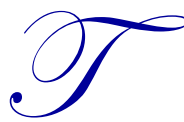

o stay competitive in today's global market place it is crucial for firms in developing countries to improve their export success. This is the only way they can be assured of continued growth and survival in the international market (Kumcu, Harcar, \& Kumcu, 1995). There have been numerous studies published in the past 30 years on the effect of export commitment on export performance (Aaby \& Slater, 1989; Sousa, 2004; Sousa, Martínez-López, \& Coelho, 2008). This large volume of publications is a strong testimony of not only the importance of the issue but also the legitimacy of inquiry into export marketing. As an area of inquiry, export marketing has been gaining increased recognition among academic disciplines as a legitimate field of research. This recognition is well reflected not only by the fact that exporting research has been published in the leading academic journals, but also by the sheer number of publications related to exporting.

Its importance and legitimacy notwithstanding, the field of exporting inquiry is known for autonomous and uncoordinated efforts (Cavusgil \& Zou, 1994). In particular, the knowledge of the impact of export commitment on export performance is still characterized by a fragmented collection of confusing findings (Zou \& Stan, 1998). A major reason for the lack of clear conclusions is the lack of synthesis and assimilation of the fragmented knowledge (Zou \& Stan, 1998).

If the issue is not new, it is still important in the academic field when observing the evolution of the literature. From 1990 to 2012 more than a hundred studies have examined the issue, more than a third in the last five years (Sousa, 2004; Sousa et al., 2008). (Aaby \& Slater, 1989; Sousa et al., 2008) showed excellent efforts in the synthesis of the literature on export performance. Unfortunately, a weakness in these syntheses has limited their ability to conclude into practice. Indeed, these studies involved a variety of measures of export performance which conceptually are broader than export performance, such as propensity to export, exporter/ non exporter dichotomy... 
The literature is still characterized by the lack of consensus of the impact of export commitment on export performance and the findings are sometimes conflicting (Zou \& Stan, 1998). These divergences may be attributed to (1) differences in methodology, in terms of design, sampling, sample size, data collection, and response rates; (2) the country of the study, the information source, and moment in time when the data were collected; (3) differences in statistical analysis, in terms of method, reliability and validity issues, discussion and interpretation of the data.

In order to avoid confusion, a more focused review on the impact of export commitment on export performance needs to be conducted. Indeed, it is worthwhile to offer an updated review of what has been accomplished in the last decade and where future research efforts should be directed. An interesting method to see the overall picture is the meta-analysis.

The aim of the present study is to provide an update review and synthesis of the empirical literature between 1990 and 2012 of the link between management export commitment and export performance and to discuss directions for future research aimed at developing better theories and advancing knowledge of export marketing. We believe that the comparison of meta-analysis techniques applied to all of the available literature can help to answer the following question: Is the impact of the commitment to export on export performance significantly positive?

Our paper combines different methods of meta-analysis. The combination of several techniques of metaanalysis allows us to combine the advantages and overcome the major drawbacks of each method. We first implement a non-quantitative meta-analysis. Second, we proceed to a quantitative meta-analysis that considers the quality of the studies. Finally, we propose to include only high quality studies.

Moreover, the use of the three meta-analyses provides a comprehensive picture of the relationship between management export commitment and export performance, proving that the positive and significant association does not change regardless of the meta-analysis used. All studies were analyzed for their conceptual, methodological, and empirical content. In conceptual terms, the review aimed to identify the link between management export commitment and export performance. On the methodological side, the research designs were evaluated in terms of fieldwork procedures, sampling processes, independent variable, dependent parameters, and analytical methods. From an empirical standpoint, hypothesized association between managerial export commitment and export performance was extracted from the pertinent literature, and the findings resulting from the empirical validation of this association were recorded.

To reach the purpose of the study and to explain its contributions, the remainder of this article is as follows. We first present a literature review on the relationship between management export commitment and export performance and the characteristics of the publications included in the present research. Second, we present respectively the characteristics and the results of non-quantitative meta-analysis and quantitative meta-analysis. We finally propose the results and conclude with a discussion of the implications of our fings for both practitioners and researchers.

\section{LITERATURE REVIEW: THE LINK BETWEEN EXPORT COMMITMENT AND EXPORT PERFORMANCE}

Commitment to export was considered in the 1960s as a key concept in the social sciences. Since, it has been studied extensively in various other contexts and disciplines (Papadopoulos \& Martin, 2010). It is one of the components of attitudinal characteristics mentioned in the previous literature (Sousa et al., 2008). Commitment to export is considered as one of the most important determinants of export performance (Navarro, Losada, Ruzo, \& Díez, 2010; Nazar \& Saleem, 2009) and explains the differences in export sales between companies.

Management export commitment can be defined as the general willingness to aggressively go after the export market opportunities, avoid international threats and undertake effective marketing strategies which improve the export success (Julian \& Nhat, 2007).

When a leader is committed to export, he is more likely to work on difficult tasks, be devoted to special efforts and allocate productive resources, technical, financial, marketing and human resources for activities related 
to export and implement in an orderly and systematic manner (O'Cass \& Julian, 2003; Stoian, Rialp, \& Rialp, 2011), which allows him to gain the opportunities to export markets, to guard against threats and develop a marketing strategy to achieve the objectives set out in international business (Zou \& Stan, 1998). The leader will be better oriented in his decisions and will be able to reap the benefits in the long term (Haghighi \& Ataei, 2010). Indeed, the more resources are involved, the higher the leader is able to improve his planning and strategy. Without proper resource allocation, a firm may find itself in the initial stages of exporting for long periods of time and may not make significant progress in tapping international markets. In our research, commitment to export is an independent variable expected to play a role in the success or failure of the export as it has been shown by several researchers (Wilkinson \& Brouthers, 2006).

We are aware that other authors such as Evangelista (1994) established that there is no significant relationship between commitment to export and export performance. This confirms the lack of consensus among researchers. Another study that investigated systematic and nonsystematic exporters found no statistically significant differences in terms of managerial commitment to exporting (Bourantas \& Halikias, 1991). Top management commitment has also been seen as critical to successful business performance in foreign markets, particularly during the early stages of internationalization (Madsen, 1994). This is confirmed in two empirical studies examining the effect of managerial commitment on export performance (Cavusgil \& Zou, 1994; Madsen, 1989).

\section{CHARACTERISTICS OF THE REVIEWED STUDIES}

The review covered the period from 1990 to 2012, when the thrust of research into exporting was conducted. We first selected articles from literature (Dhanaraj \& Beamish, 2003; Evangelista, 1994) on the relationship between management commitment and export performance. We have covered the studies through available databases which are EBSCO, Science Direct, JSTOR, Emerald, Proquest and Google Scholar with the keywords search "export performance" and "management export commitment". The studies included in this paper were identified using a combination of electronic and manual bibliographic search methods. The manual search, on the other hand, was directed at sorting through the articles published in major marketing and international business journals, tracking down those articles listed in the references of major export performance studies, and searching the books on exporting.

Sixty-five publications in English were finally included in our study. We excluded studies lacked sufficient information regarding statistics and results and those that not address direct effect of management export commitment to export performance. The majority of the 65 studies were published in Journal of Business Research, International Marketing Review and Journal of International Business Studies. The differences on the export commitment and export performance, the heterogeneity of the methodology can explain the conflicting findings obtained in the different studies on the subject.

\subsection{Scope Of The Review}

The goal of this research is to trace the new developments in the last decade and identify trends in export performance research. Publications before 1989 are not included, as Madsen, 1987 has offered valuable reviews of those pieces. There are three major criteria used in selecting the articles for review. First, the articles have to be empirical in nature, reporting data analysis and statistical tests. Second, the articles have to use some kind of export performance measures as dependent variables. Third, the articles must be cross selectional in nature. Case studies are not included nor are studies that have appeared in non-English publication outlets. It was difficult to access nonEnglish publications due to the non-availability of the printed form of these studies outside the countries of publication and the non-inclusion of most of these journals in electronic databanks.

\subsection{Overall Rating Of The Studies Reviewed}

As the findings tend to be idiosyncratic in relation to the research methodology employed (Leonidou, Katsikeas, \& Samiee, 2002), it is essential to examine the methodological aspects of the studies included in this review. Consequently, the research methodologies used in the studies were evaluated along the following 
dimensions: country of investigation, firm size, industrial sector, theoretical basis adopted, sample size, data collection, unit of analysis and statistical analysis.

\subsection{Country Of Investigation}

The U.S. is the most studied country in export performance between the periods 1990 to 2012. A large number of studies have been conducted in several other countries. Of the 65 papers included in our meta-analysis, 29 studies were conducted in the USA. An important contribution has been made by European researchers from non-English-speaking countries who conducted studies in the contexts of their home countries and published in English-language journals, and in Asia and Latin America have also been studied researchers (Cadogan, Cui, \& YeungLi., 2003; Das, 1994; DeLuz, 1993). This is a clear indication that export performance research has gained recognition around the world. It can be expected that this trend will help enrich the knowledge of the link between export commitment and export performance.

\subsection{Firm Size}

The overwhelming majority of studies investigated the subject from the perspective of small to mediumsized enterprises (SMEs), and larger units were the focus of attention of just 18 studies (Balabanis, Theodosiou, \& Katsikea, 2004). This can be explained by several factors. First, smaller firms account for the largest part of the manufacturing base in most countries, thus increasing the likelihood of export engagement. Second, the well-known limitations of smaller companies in terms of personnel, production, financial and other resources create serious handicaps for export development, which need to be removed through proper assistance. Finally, despite resource constraints, smaller units can be formidable competitive forces in international business and can contribute to job creation, technological innovation, and economic development.

The criteria to measure the firm size differed among studies (e.g. number of employees, annual sales) making comparisons difficult. Second, because of the geographic focus of these studies, the meaning of the terms 'small', 'medium', and 'large' varies greatly in an international context.

\subsection{Industrial Sector}

Only 5 studies (Dominguez \& Sequeira, 1993; Louter, Ouwerker, \& Bakker, 1991; Samiee \& Walters, 1990; Singer \& Czinkota, 1994; Sriram \& Manu, 1995) included in their samples reselling and service firms in addition to manufacturers. While this may reflect the importance of manufacturing exports in the world economy (Leonidou \& Katsikeas, 1996), the generalizability of the findings to other industry contexts should not be automatically assumed. Researchers should focus more on service firms in order to elucidate the specific problems posed by the unique characteristics of services, such as intangibility.

\subsection{Theoretical Basis Adopted}

Only a few studies have built upon an explicit theoretical basis. Nevertheless, quite a few studies have made a conscious effort to derive their research hypotheses with clear reference to some theoretical and conceptual frameworks, such as the strategy-structure-performance paradigm.

While the trend toward more theoretical reasoning is encouraging, the literature still has a long way to go before reaching theoretical maturity. In fact, about half of the studies reviewed here did not contain theoretical reasoning in developing the research questions or hypotheses. This is somewhat surprising given the fact that (Aaby \& Slater, 1989; Sousa et al., 2008) had proposed a "strategic management model" of export performance, and (Cavusgil \& Zou, 1994) had provided a broad conceptual framework that delineates the relationships between the internal and external factors, export marketing strategy, and export performance. It appears that researchers need to be more conscious about the theoretical logic when conducting their studies. 


\subsection{Sample Size}

Studies conducted in the 1990s tended to use small sample sizes with fewer than 150 firms (Leonidou et al., 2002). The size of sample used in the reviewed studies sizes ranged from a minimum of 50 to a maximum of 783 firms, with a median sample size of 181 and a mean around 232. This constitutes relatively high sample sizes and indicates a tendency to use larger samples which allows for more sophisticated statistical analysis. For studies which reported small sample sizes, external validity and generality can be questioned. The sample itself may not be representative of the population and it also limits the use of adequate statistical analysis to test the relationships. Therefore, specific conclusions are attenuated and should be regarded as suggestive rather than conclusive.

\subsection{Data Collection}

Only empirical research was considered because of the need to validate the asserted relationships between export commitment and various export dimensions. The data collection approach most commonly employed was the mail survey, which was adopted in approximately three quarters of the studies. Interestingly, mail surveys were more often employed in the United States for relatively large samples, while the personal method was associated with small sample sizes. Telephone interviewing was not used at all, while three other studies did not disclose the data gathering method utilized.

In most studies data were collected from the individual responsible for international marketing activities, namely the export manager. Nevertheless, the CEO, president, vice president, managing director, or marketing director also provided the information requested. However, the tendency to view firms as having only one decision maker is misleading, since decisions are made often made by more than one person, especially in larger firms (Leonidou \& Katsikeas, 1996).

\subsection{Unit Analysis}

Approximately more than half of the studies reviewed here used the firm as the unit of analysis. In the case of using the firm as the unit of analysis, the export performance construct is assessed in the context of the firm's overall activities in international markets. This can be attributed to the greater willingness of key informants to disclose information at this broad level (Matthyssens \& Pauwels, 1996).

The majority of studies, however, one included both exporters and non-exporters, in order to compare and contract their export commitment. One problem of any attempt to divide these two broad categories into subgroups of firms, such as marginal and committed exporters, or uninterested non exporters and exporter intenders, resulting in a somewhat crude analysis.

\subsection{Analytical Approach}

The majority of the studies used multivariate statistical methods, primarily multiple discriminant analysis, principal components analysis, and multiple regression analysis. Both frequency distributions and mean scores were used extensively as auxiliary statistical tools to establish the relative importance of management export commitment. In the vast majority of studies, causality problems appear to exist between the independent variable and the dependent variables. For instance, does management commitment lead to high export performance, or is a good export performance the cause of management commitment?

Table 1 shows the characteristics of the articles collected for our meta-analysis. 
Table 1. Characteristics Of The 65 Articles Analyzed For This Research

\begin{tabular}{|c|c|c|c|c|c|c|c|}
\hline Authors, Date & $\begin{array}{c}\text { Country } \\
\text { of the study }\end{array}$ & $\begin{array}{c}\text { Industry } \\
\text { type }\end{array}$ & $\begin{array}{c}\text { Sample } \\
\text { Size } \\
\end{array}$ & Firm size & $\begin{array}{c}\text { Data } \\
\text { collection }\end{array}$ & $\begin{array}{c}\text { Unit } \\
\text { Analysis } \\
\end{array}$ & $\begin{array}{l}\text { Statistical } \\
\text { Approach }\end{array}$ \\
\hline Atuahene-Gima, 1995 & US & - & 275 & - & survey & exventure & $\begin{array}{l}\text { discriminant/ } \\
\text { reg }\end{array}$ \\
\hline Axinn et al., 1996 & US & manuf & 75 & SM & survey & firm & $\begin{array}{l}\text { regression/ } \\
\text { structural eq }\end{array}$ \\
\hline Axinn et al., 1995 & US & manuf & 77 & SM & survey & firm & anova \\
\hline Axinn \& Thach, 1990 & US/ CANADA & - & 101 & - & survey & firm & t-test \\
\hline Beamish et al., 1993 & UK/ CANADA & manuf & 197 & SM & survey & firm & correlations \\
\hline Bijimolt \& Zwart, 1994 & NETHERLANDS & - & 248 & SM & survey & firm & structural eq \\
\hline Bodur, 1994 & Turkey & manuf & 88 & - & interv & firm & discriminant \\
\hline Cavusgil \& Zou, 1994 & US & manuf & 202 & $\mathrm{M}$ & interv & exventure & structural eq \\
\hline $\begin{array}{l}\text { Cavusgil \& Kirpalani, } \\
1993\end{array}$ & $\begin{array}{l}\text { US/ CANADA/ } \\
\text { JAPAN }\end{array}$ & manuf & 130 & SML & second & exventure & chi-square \\
\hline Chan, 1992 & $\begin{array}{c}\text { HK/ } \\
\text { SINGAPORE }\end{array}$ & manuf & 122 & SM & survey & firm & correlations \\
\hline Culpan, 1989 & US & manuf & 210 & SM & survey & firm & chisq/ discrim \\
\hline Czinkota \& Ursic, 1991 & US & manuf & 174 & SM & survey & firm & anova \\
\hline Das, 1994 & INDIA & - & 58 & SM & interv & firm & chisq/ discrim \\
\hline DeLuz, 1993 & BRAZIL & manuf & 31 & - & survey & firm & regression \\
\hline $\begin{array}{l}\text { Diamantopoulos \& } \\
\text { Schlegelmilch, } 1994 \\
\end{array}$ & $\begin{array}{c}\text { US/ UK/ } \\
\text { GERMANY }\end{array}$ & manuf & 296 & - & survey & firm & $\begin{array}{l}\text { regression/ } \\
\text { ancova }\end{array}$ \\
\hline $\begin{array}{l}\text { Dominiguiz \& Squeira, } \\
1993\end{array}$ & $\begin{array}{l}\text { CENTRAL } \\
\text { AMERICA }\end{array}$ & $\begin{array}{l}\text { manuf/ } \\
\text { reseller }\end{array}$ & 253 & - & interv & firm & cluster/ ancova \\
\hline Donthu \& Kim, 1993 & US & manuf & 640 & SM & survey & firm & discrim \\
\hline Evangelista, 1994 & AUSTRALIA & manuf & 193 & & survey & firm & discrim \\
\hline Gray, 1997 & N ZELAND & - & 300 & SM & survey & firm & cluster/ ancova \\
\hline $\begin{array}{l}\text { Holzmuller \& Kasper, } \\
1991\end{array}$ & AUSTRIA & manuf & 103 & SM & survey & firm & structural eq \\
\hline $\begin{array}{l}\text { Holzmuller \& Stottinger, } \\
1996\end{array}$ & AUSTRIA & manuf & 101 & SM & survey & firm & structural eq \\
\hline Ito \& Pucik, 1993 & JAPAN & manuf & 271 & $\mathrm{~L}$ & second & firm & regression \\
\hline Katsikeas et al., 1996 & GREECE & manuf & 87 & $\mathrm{SM}$ & interv & firm & regression \\
\hline Kaynak \& Kuan, 1993 & TAIWAN & manuf & 140 & SML & survey & firm & discriminant \\
\hline Koh, 1991 & US & manuf & 233 & - & survey & firm & anova \\
\hline Lee \& Yang, 1990 & US & manuf & 52 & SM & interv & firm & anova \\
\hline Lim et al., 1996 & US & manuf & 438 & SM & survey & firm & regression \\
\hline Louter et al., 1991 & HOLLAND & $\begin{array}{l}\text { manuf/ } \\
\text { reseller }\end{array}$ & 165 & SM & survey & firm & structural eq \\
\hline Madsen, 1989 & Denmark & manuf & 134 & SM & survey & exventure & regression \\
\hline Moini, 1995 & US & manuf & 102 & SM & survey & firm & anova/discrim \\
\hline Naidu \& Prasad, 1994 & US & manuf & 728 & SM & survey & firm & chisq/logreg \\
\hline Namiki, 1994 & US & manuf & 106 & $\mathrm{M}$ & survey & firm & anova \\
\hline Patterson et al., 1997 & Australia & services & 181 & SML & survey & firm & regression \\
\hline Raven et al., 1994 & US & reseller & 118 & $\mathrm{~S}$ & survey & firm & regression \\
\hline Samiee \& Walters, 1990 & US & $\begin{array}{l}\text { manuf/ } \\
\text { reseller }\end{array}$ & 145 & SL & survey & firm & t-test/chisq \\
\hline Seifert \& Ford, 1989 & US & manuf & 65 & SM & survey & firm & anova \\
\hline Shoham, 1996 & US & manuf & 81 & SML & survey & firm & regression \\
\hline Singer \& Czinkota, 1994 & US & $\begin{array}{c}\text { manuf/res } \\
\mathrm{el} / \mathrm{serv}\end{array}$ & 89 & SML & survey & firm & chisq/logreg \\
\hline Striam \& Manu, 1995 & US & $\begin{array}{c}\text { manuf/res } \\
\text { el/ serv }\end{array}$ & 121 & SML & survey & exventure & regression \\
\hline Walters, 1993 & US & manuf & 141 & - & survey & firm & anova \\
\hline Walters \& Samiee, 1990 & US & manuf & 145 & SL & survey & firm & t-test/ chisq/reg \\
\hline Zou et al., 1997 & Colombia & manuf & 51 & ML & survey & firm & regression \\
\hline
\end{tabular}


(Table 1 continued)

\begin{tabular}{|c|c|c|c|c|c|c|c|}
\hline Cadogan et al., 2002 & Finland & $\begin{array}{l}\text { multiple } \\
\text { industries }\end{array}$ & 783 & - & survey & firm & structural eq \\
\hline Cicic et al., 2002 & Australia & $\begin{array}{l}\text { multiple } \\
\text { industries }\end{array}$ & 181 & - & survey & firm & structural eq \\
\hline $\begin{array}{l}\text { Balabanis and Katsikea } \\
(2003)\end{array}$ & UK & $\begin{array}{l}\text { multiple } \\
\text { industries }\end{array}$ & 82 & SML & survey & firm & structural eq \\
\hline O'Cass and Julian (2003) & Australia & $\begin{array}{l}\text { multiple } \\
\text { industries }\end{array}$ & 293 & SML & survey & exventure & structural eq \\
\hline Cadogan et al., 2003 & HONG KONG & $\begin{array}{c}\text { multiple } \\
\text { industries }\end{array}$ & 137 & ML & survey & firm & structural eq \\
\hline Dharanaj \& Beamish, 2003 & USA/ CANADA & $\begin{array}{l}\text { multiple } \\
\text { industries }\end{array}$ & $87 / 70$ & SM & survey & firm & structural eq \\
\hline Morgan et al., 2004 & USA & $\begin{array}{l}\text { multiple } \\
\text { industries }\end{array}$ & 287 & SM & survey & firm & structural eq \\
\hline Lages \& Lages, 2004 & Portugal/ UK & $\begin{array}{l}\text { multiple } \\
\text { industries }\end{array}$ & $519 / 111$ & SM & survey & exventure & structural eq \\
\hline $\begin{array}{l}\text { Lages \& Montgomery, } \\
2004\end{array}$ & Portugal/ UK & \begin{tabular}{|c|} 
multiple \\
industries
\end{tabular} & 413 & SM & survey & exventure & structural eq \\
\hline Yeoh, 2000 & USA & $\begin{array}{l}\text { multiple } \\
\text { industries }\end{array}$ & 180 & MI & survey & firm & $\begin{array}{l}\text { correlation, } \\
\text { regression }\end{array}$ \\
\hline Stewart \& McAuley, 2000 & CANADA/ UK & $\begin{array}{l}\text { multiple } \\
\text { industries }\end{array}$ & $207 / 160$ & $\mathrm{~S}$ & survey & firm & anova \\
\hline Albaum \& Tse, 2001 & HONG KONG & \begin{tabular}{|c|} 
multiple \\
industries
\end{tabular} & 183 & SML & survey & firm & REGRESSION \\
\hline Richey \& Myers, 2001 & USA & $\begin{array}{l}\text { multiple } \\
\text { industries }\end{array}$ & 404 & ML & survey & exventure & structural eq \\
\hline Gençturk \& Kotabe, 2001 & USA & $\begin{array}{l}\text { multiple } \\
\text { industries }\end{array}$ & 162 & SM & survey & firm & nova, regression \\
\hline $\begin{array}{l}\text { Stottinger \& Holzmuller, } \\
2001\end{array}$ & USA & $\begin{array}{c}\text { multiple } \\
\text { industries }\end{array}$ & & SM & survey & exventure & regression \\
\hline $\begin{array}{l}\text { Ling-Yee \& Ogunmokun, } \\
2001\end{array}$ & CHINA & $\begin{array}{c}\text { multiple } \\
\text { industries }\end{array}$ & 111 & SM & survey & exventure & regression \\
\hline Shoham et al., 2002 & AUSTRALIA & $\begin{array}{l}\text { multiple } \\
\text { industries }\end{array}$ & 193 & SM & survey & firm & regression \\
\hline Brouthers \& Xu, 2002 & CHINA & $\begin{array}{l}\text { multiple } \\
\text { industries }\end{array}$ & 88 & SML & survey & firm & $\begin{array}{c}\text { correlation, } \\
\text { regression }\end{array}$ \\
\hline Cadogan et al., 2002 & CHINA & \begin{tabular}{|c|} 
multiple \\
industries
\end{tabular} & 206 & - & survey & firm & structural eq \\
\hline Rose \& Shoham, 2002 & ISRAEL & $\begin{array}{l}\text { multiple } \\
\text { industries }\end{array}$ & 124 & SML & survey & exventure & $\begin{array}{c}\text { correlation, } \\
\text { regression }\end{array}$ \\
\hline Myers, 1999 & USA & \begin{tabular}{|l} 
multiple \\
industries
\end{tabular} & 404 & ML & survey & exventure & gression, manova \\
\hline white et al., 1998 & USA & $\begin{array}{c}\text { multiple } \\
\text { industries }\end{array}$ & 124 & SML & survey & firm & regression \\
\hline
\end{tabular}

\subsection{Measures}

In the remaining studies, management commitment was examined in relation to export performance, which was usually expressed in financial terms, such as export sales, ratio of export sales to total sales, profitability in overseas markets, and growth of export sales and profits. These studies have come under increasing criticism, because they fail to operationalize explicitly the performance of the firm in overseas markets. This can be attributed to the fact that, on the one hand, export performance measures are used independently of each other, and on the other, many other useful measures, such as the rate of new market expansion or new product introduction, are not taken into consideration. 


\subsubsection{Measures Of Export Performance}

As with any measure, export performance measures consist of conceptual and operational definitions. The conceptual definition attempts to define export performance. The operational definitions establish how export performance can be measured. A conceptual definition of export performance should address each of the two parts: export and performance. Export is defined conceptually as the composite outcome of a firm's international sales (Shoham, 1996). This is a conceptual definition and is, therefore, inclusive of several international engagements.

It is essential to recognize the central importance of performance in any discussion about strategy, including international strategy. This importance is due to success being a pivotal outcome construct in the study of international strategy.

The export performance is defined as the ability of the firm to combine its resources and its competencies (Barney, 1991; Newbert, 2007). Both the conceptual and operational definitions of export performance should depend on the more general and inclusive definitions of firm and marketing performance. In addition, firms hold different concepts of performance including employees, top management or other groups that may affect the exporter's operations. Any definition of international performance is context-specific. The conceptual definition of performance depends on the research context of a given study.

The number of studies published over the past decades on the subject of export performance is testimony to the importance of the issue in the literature. However, researchers do not agree on its conceptual nor operational definition, which frequently leads to incoherent and contradictory results (Katsikeas, Leonidas, \& Morgan, 2000). Comparing studies using different indicators is difficult, as is generalizing their conclusions (Styles, 1998).

Measurement of export performance has varied widely in the export literature and no single measure or construct definition dominates the field (Sousa et al., 2008).

Most researchers accept the unidimensionality of the export performance (Sousa et al., 2008; Zou, Taylor, \& Osland, 1998). For example, Zou et al. (1998), building on (Cavusgil \& Zou, 1994) model, propose a scale that incorporates objective, strategic and subjective measures of export performance. Different terms have been used in explaining export performance.

Among them are international performance (Ural, 2009), international market place performance (O'Cass \& Weerawardena, 2009), economic international performance, export performance (Bijmolt \& Zwart, 1994). It can also be seen that there are many measures of export performance used over the years.

Export performance has been broadly measured using financial or objective measures (sales, profit), nonfinancial or subjective measures (satisfaction, goal achievement) and also composite measures. Export sales have been used by a majority of researchers to measure export performance. They include (Köksal, 2008; Shamsuddoha \& M, 2006; Ural, 2009)). Export sales growth has also been used as form of export performance measure. Other forms of measures are export profit (Blesa \&'s, 2008; Shamsuddoha, 2004) and profitability (Lages \& Montgomery, 2005; O'Sullivan \& Butler, 2009; Ural, 2009). Satisfaction have been measured in terms of customer (O'Cass \& Weerawardena, 2009), market performance (O'Sullivan \& Butler, 2009), level of export performance (Lee \& Griffith, 2004) and export operation (Akyol \& Akehurst, 2003).

(Racela \& Chaikittisilpa, 2007) measure satisfaction on a variety of criteria such as export sales, export profitability, export market share and rate of new market entry. Market share achievement has also been used to measure export performance level by (Köksal, 2008; O’Cass \& Weerawardena, 2009; Ural, 2009). Measuring export performance through export intensity is applied by (Akyol \& Akehurst, 2003; Francis \& Collins-Dodd, 2004; Suarez \& Vera, 2005). (Akyol \& Akehurst, 2003; Lages \& Montgomery, 2004) used overall market performance as a form of measure.

Thus, it can be seen that there are many measures of export performance used over the years. Export performance is measured using financial export performance, strategic export performance and satisfaction with the 
export venture. The measurement of export development or export expansion has not been researched widely in internationalization related studies. Among the existing studies, (Francis \& Collins-Dodd, 2004) referred export development as export expansion. Among the measurements used are in terms of new markets and/or new products, new geographic or new product markets (next year and the next three years) and increase export intensity "next year" and "next three years". Entering new markets is also used by (O'Cass \& Weerawardena, 2009); however, it is used to measure export performance, while rate of new market entry is applied by (Racela \& Chaikittisilpa, 2007) for measuring performance satisfaction. (White, Griffith, \& Ryans, 1998) on the other hand use development of firms' market to measure the effect of internationalization in the future. (Lim, Sharkey, \& Heinrichs, 2006) use measures such as 'expand their export sales through additional product introduction' and 'expand their export sales through international market expansion' among others to measure export market involvement.

We can conclude that there is no consensus and no agreement for definition and measures of export performance (Navarro et al., 2010), and export sales, profits, and composite sales are probably the most frequently used measures of export performance (Zou \& Stan, 1998), despite recent recommendations for using perceptual measures of overall export performance in achieving organizational goals (Sousa et al., 2008).

The unidimensionality of the export performance may explain Bonoma \& Clark (1988) comment that perhaps no other concept in marketing's short history has proven as stubbornly resistant to conceptualization, definition, or application.

\subsubsection{Measures Of Export Commitment}

To operationalize "export commitment" construct, several items were adopted from relevant literature (Brodrechtova, 2008). Respondents in majority of the studies were asked to indicate their level of agreement with each statement on a seven-point scale ranging from 1 (strongly disagree) to 7 (strongly agree).

\section{CONDUCTING META-ANALYSIS}

A systematic synthesis of the existing studies and frameworks is needed to understand better the effect of management export commitment on export performance. To this aim, in the light of the studies included in our research, we first implement a non-quantitative meta-analysis.

Meta -analysis was first used by Pearson in 1904. It has gained momentum especially since 1970.

\subsection{Non Quantitative Meta-Analysis}

We first use the vote counting method. The available studies are sorted into three categories: those that report significant results in the predicted direction, those that yield significant results in the opposite direction and those that yield non-significant results.

Second, we implement a combined significance tests that tests the null hypothesis (there is no relationship between management export commitment and export performance).

Third, we present their contributions and limitations.

\subsubsection{The Vote Counting Method}

The vote counting method is limited to answer to the simple question "is there any evidence of an effect?"

In its simplest form, we first classified the results of the included publications into three categories: positive significant relationship (+), negative relationship (-) and no significant relationship (n.s).

The advantages of the vote counting methods are the simplicity in their application. In fact, all the studies are included instead of the sample size, the statistical approach and design. However, the vote counting method does not provide the relevant informant in synthesizing the results of different studies. Second, we used a sign test to 
evaluate the significance of evidence for the existence of an effect in either direction. In fact, if we found no relationship the studies will be distributed evenly around the null hypothesis of no difference.

The positive relationship means that the probability of obtaining a positive result is significantly higher than 0.5 . In fact, $\mathrm{H} 0 \pi=0.5$ is conventionally used to denote the null hypothesis and $\mathrm{H} 1 \pi 1>0.5$ the alternative. 0.5 is the traditional value used (Conover, 1980).

The table 2 proposes the results of the vote counting method.

Table 2. Results Of The Vote Counting Method

\begin{tabular}{lcccc}
\hline & All the studies & pv $\leq .1$ & pv $\leq .05$ & pv $\leq .01$ \\
\hline Positive results & 49 & 40 & 35 & 27 \\
Total results & 65 & 52 & 47 & 38 \\
Sign test & .75 & .77 & .74 & .71 \\
Probability value (p-value) under H0 & $\mathrm{p}<.0001^{* * *}$ & $\mathrm{p}<.0001^{* * *}$ & $\mathrm{p}<.0001^{* * *}$ & $\mathrm{p}<.0001^{* * *}$ \\
\hline
\end{tabular}

H0: No positive and significant results.

The hypothesis of no positive and significant results between management export commitment and export performance is rejected. In fact, the results showed in table 2 concluded of a positive and significant relationship between the two variables in the two cases (all studies and only taking into account low pv). This result demonstrates the appropriateness of studies included according to their corresponding $\mathrm{p}$ values.

\subsubsection{Testing The Null Hypothesis: Combined Significance Tests}

The combined significance approach tests the null hypothesis that the effect of an independent variable on a dependent variable is zero in all studies. This approach emphasizes the characterization of the magnitude of the combined effect.

Becker (1994), Hedges \& Olkin (1985), and Rosenthal (1978) described two types of methods:

- $\quad$ The method of the minimum p-value and the average p-values, that assume uniformity of distribution of $p$ values. (Originally developed by Tippet (1931)).

- The sum-of-logarithm-distribution, based on the transformation of p-values to obtain a combined significance level. (Developed by Fisher (1932)).

The findings presented in the literature review on the relationship between management export commitment, show that there is more non-significant results (n.s) than significant results (+) and (-).

Using the sum-of-logarithm process and the method of the minimum p-value are inappropriate.

Using the average p-value for conducting this research is more powerful than the sum of logs summary and other techniques (Kozil \& Perlman, 1978).

The average p-value method is used to test the null hypothesis from a sum of values.

The table 3 proposes the results of the combined significance tests.

Table 3. Results Of The Combined Significance Tests

\begin{tabular}{lcccc}
\hline & All the studies & $\mathbf{p v} \leq .1$ & $\mathbf{p v} \leq . \mathbf{0 5}$ & $\mathbf{p v} \leq \mathbf{. 0 1}$ \\
\hline Average p-value & 14.76 & 11.21 & 11.06 & 10.56 \\
Cumulative significance level & $\mathrm{p}<.0001^{* * *}$ & $\mathrm{p}<.0001^{* * *}$ & $\mathrm{p}<.0001^{* * *}$ & $\mathrm{p}<.0001^{* * *}$ \\
\hline
\end{tabular}

The results shown in table 3 concluded of the positive and significant relationship between management export commitment and export performance. Hence, the findings of the combined significance tests confirm the findings of the vote counting method. 
In fact, there is at least one significant result.

The non-quantitative meta-analysis may lead to wrong conclusion about the overall outcome across studies. In fact, the statistical significance of the research findings has power for effects of relatively small magnitude. Not all studies included provide adequate data for inclusion and analysis.

On the basis of the issue raised, can we conclude on the significant effect of management export commitment on export performance?

These methods give more weigh to studies using different measurement scales for a specific construct with a heterogeneity of study populations (Slavin, 1995).

They do not allow quantifying the effect of one variable on another. Slavin (1995) considers that this technique provides only a response for the effect of the independent variable on the dependent variable, without any estimate of this effect.

Conducting a quantitative meta-analysis is a crucial step to assess the relationship between management export commitment on export performance. In fact, we can estimate this effect only with quantitative meta-analyses.

\subsection{Quantitative Meta-Analysis}

The goal of quantitative meta-analysis is to address the gap in quantifying the effect of one variable on another. The aim of quantitative meta-analysis is to estimate the effect of an independent variable on an outcome variable based on the estimated effects of the studies included.

Quantitative meta-analyses can be mobilized only to synthesize results from studies using regression to estimate the relationship between two variables (Bonache et al., 2012).

The use of quantitative meta-analysis is very interesting since it allows to quantify the effect studied, thus exceeding the limits of the non-quantitative meta-analysis.

It is advisable to perform analyses both with and without quality scores and exclude studies that do not provide appropriate statisctical results.

\subsubsection{Inclusion Of Study Quality Score}

Results from better quality studies are more valid than results from other studies.

It is important to consider the internal and external validity of the items and the relevance of the scales used to weigh their quality. We propose the implementation of this method, a discussion of the results and their limitations.

The studies on the relationship between management export commitment and export performance use different methods and constructs for each variable and the results are very frequently different. The meta-analysis is a research method designed to pool different small series from various studies in order to reach a conclusion in this subject where there is no general agreement between different authors. By pooling various little series, the number of studies is more important; hence the power of the study is stronger. It is therefore important that the following conditions be met: Studies must report clear informations in terms of design, sampling, sample, size, data collection and response rate. Obviously, the various studies must be on the same nature and use the same scales, unit of analyses and definitions of constructs.

A quality score was assigned to these studies according to the following criteria and the use of the appropriateness methods was evaluated. The score is given examining the precision of the country of investigation, the size of the sample, the type of firms targeted, the data collection methods, the theoretical basis adopted, the 
precisions of the analytical approaches ( $\mathrm{t}$-test, chi-square test, ANOVA, ...). The lower score is given to articles do not precise these conditions.

The score range from 0.5 to 1.1. on our sample of articles. Using the scale of Cavusgil and Zou (1994) to measure commitment to export, and that of Cavusgil \& Zou (1994) and Zou, Taylor \& Osland (1998) to measure the export performance were used according to the literature. If they measure commitment with a scale based on that of Cavusgil and Zou (1994), the score is .10. No score is assigned in other cases. We did the same with the scale of Cavusgil and Zou (1994) and Zou et al. (1998) for export performance. The quality score is determined according the above criteria.

The sample finally consisted of 52 studies. The statistical presentation of these publications allows a quantitative meta-analysis.

Once the quality score is identified, the effect sizes should be calculated.

\subsubsection{Exclusion Of Study Quality Score}

We have calculated the effect sizes without quality scores to evaluate the results' sensitivity of the quantitative meta-analysis on the relationship between commitment to export and export performance.

Hence, the comparison between statistical tests with and without quality scores can control the impact of subjectivity linked to quality scores that could biase the results. In making a report of a meta-analysis, it is thus desirable to find this comparison so that the results of the meta-analyses be discussed carefully (Bonache et al., 2012).

The table 4 presents the results of the quantitative meta-analysis with and without taking into account quality score of items.

Table 4. Results of the quantitative meta-analysis with and without quality score (QS)

\begin{tabular}{lcc}
\hline & With QS & Without QS \\
\hline Estimate of common effect & $.009^{* * *}$ & $.141^{* * *}$ \\
Variance of the estimator & .001 & .001 \\
Test statistic & 6,018 & 28.401 \\
\hline
\end{tabular}

*** $\mathrm{p}<.001$

The results of the quantitative meta-analysis of all studies used are positive: Without quality score, the relationship between commitment to export and export performance is positive and significant. Considering the quality score, this link is also positive and significant.

We can conclude that with or without quality scores, the relationship between management export commitment and export performance is positive significant.

Although quality would be captured in one dimension, the use of quality scores in summarization weights would biase estimated of effect. In this way, quality weighting should be evaluated against formal bias-variance trade-off methods such as hierarchical meta-regression (Greenland \& Rourke, 2001).

Slavin (1995) recommended using a quantitative meta-analysis called the "best synthesis analysis" with the selection of the studies with the strongest design.

\subsection{An Intelligent Alternative To Meta-Analysis}

Slavin (1995) proposed to retain only the best studies "best synthesis analysis". How the relevant high quality studies can be identified? 
The principal of best synthesis analysis is to retain the homogeneous works in terms of the method. retained the studies randomly drawn from the sample, improving the robustness of the results we retained (Yin, 2009). The best studies were performed on 27 studies. We highlight that the results can be affected by the quality scores attributed to the pooled series as this can produce biased estimates of effect. Hence, the researcher has to exert his own judgments to avoid such a bias.

We also conduct analyzes without quality score to limit potential bias. In this way, if the researchers are interested by replication of this study, they can build their own quality scores and it would be interesting to compare their results to ours. In fact, replication studies could contribute to the development of the theory concerning our subject of study.

The table 5 proposes the results of best synthesis analysis with and without quality scores.

Table 5. Results Of Quantitative Meta-Analysis "Best Studies"

\begin{tabular}{lcc}
\hline & With QS & Without QS \\
\hline Estimate of common effect & $0,119^{* * *}$ & $0,227^{* * *}$ \\
Variance of the estimator & 0,002 & 0,002 \\
Test statistic & 0,627 & 24,322 \\
\hline
\end{tabular}

$* * * \mathrm{p}<.001$

We found the same results when retaining the first study based on a random sample in the both cases, and by retaining then only articles published in journals classified by CNRS, AERES and FNEGE.

\section{CONCLUSION: DISCUSSION OF MAIN FINDINGS AND AVENUES FOR FUTURE RESEARCHES}

The literature on the relationship between management commitment and export performance is important and its results being ambiguous, this article makes a comprehensive and quantified synthesis. Significant progress has been made in the last decade in developing better theory and knowledge of the impact of management export commitment on export performance. A key point to make here is that, compared to earlier studies reviewed by (Aaby \& Slater, 1989; Chetty \& Hamilton, 1993), more studies in the last decade have incorporated some theoretical reasoning in developing their research questions and hypotheses. Indeed, several studies (Cavusgil \& Zou, 1994; Holzmüller \& Stöttinger, 1996) have used explicit conceptual models to guide their hypothesis development.

Although compared to earlier studies (Sousa, 2004; Zou \& Stan, 1998), some progress has been made in developing theory and knowledge of the measures of export performance, there is still a long way to go before it is possible to clearly delineate the domain of this construct and identify its dimensions. Indeed, the export marketing literature has been criticized for providing only fragmented results and for not being able to develop a widely accepted model of export performance, thus limiting theoretical advancement in this field (Morgan, Kaleka, \& Katsikeas, 2004; Sousa et al., 2008). However, these developments in the last decade have significantly strengthened the theoretical foundation of export performance research, legitimizing the academic inquiry in the field of exporting.

Our review synthetizes 65 articles published on the subject has revealed that studies use either the firm level or the export venture as the unit of analysis. The vast majority of the reviewed studies assessed export performance at the firm level ( 28 out of 43 ), which can be explained by the greater willingness of respondents to disclose information at this broad level (Matthyssens \& Pauwels, 1996). The selection of the unit of analysis is important for the correct operationalization of export performance, since a study at the firm level seeks success determinants describing the overall export activity of a firm; whereas a study at the venture level focuses on performance determinants of a particular product/market combination.

An interesting method to synthesize the literature on the subject is meta-analysis. The results of the combinaison of significance levels show that at least one result is significant. However, we can't estimate the effect of one variable on another with this method, hence the use of the vote counting method. The use of the quantitative 
meta-analysis is more powerful. We found a positive and significant effect of management export commitment on export performance when using a quality score and Best Synthesis Analysis (Slavin, 1995).

This article provides an updated review and synthesis of the empirical literature of the effect of management export commitment on export performance. The results presented in this work should be interpreted with caution because the majority of studies included in our meta-analysis and in general who are interested in this topic have been established in developed countries.

The present study also assessed collective usefulness of the empirical literature related to the strong positive influence of management commitment on export performance in a specialized, detailed, and integrated fashion. Conceptually, this stream of research is still in its exploratory phase of development, lacking a well-defined theoretical framework that would link managerial export commitment to firms' export performance. This can be attributed to the fact that most studies on the subject vary in terms of time frames, geographical focus, and industrial coverage; and the tendency to establish relationships between export commitment and export performance without connecting the results to a specific research program. As a result, this body of knowledge, consistent with the trend in the overall stream of exporting research, could be described as not being well grounded in theory.

Methodologically, there is a great diversity in the methods employed, particularly with respect to sampling designs, fieldwork procedures, and analytical techniques. One possible explanation for this lies in that research on the subject was conducted by independent researchers around the world at different points in time. The majorities of studies are one-off in nature and have a strong ethnocentric orientation, largely attributable to resource constraints to conduct longitudinal research on a cross-cultural basis. Most of this research also suffers from certain methodological handicaps, such as insufficient construct operationalization, which, however, have to be explained by the fact that an individual study, as opposed to a collaborative effort, can only make incremental contributions.

With few exceptions, the research designs employed appear not to have built upon the strengths nor to have avoided the weaknesses of previous studies, although there has been a slow increase in the methodological sophistication of research in this field over time. Finally, the focus of studies reviewed was relatively diffused, probably due to the absence of a central agency that would coordinate the whole research effort on the subject. Empirically, the most widely investigated dependent variable (export performance) was of an objective measure. The export dimension that received most empirical attention was export intensity, which also exhibited the strongest association with management export commitment.

Notwithstanding, the above conceptual, methodological, and empirical limitations, this type of research has made a number of substantial contributions to researchers, managers, and governments. From a research point of view, it has alerted exporting researchers to the potential role of management export commitment play in initiating, developing and sustaining export business. Indeed, this review has indicated that this variable is highly associated with particular facets of exporting. From a managerial standpoint, this stream of research has helped practitioners create a profile in their organizations that would be conductive to a formidable and successful engagement in exporting.

From a government perspective, research on the subject has guided public policy officials to understand that well-designed export promotion programs are effective only to the extent that targeted companies have a committed team who is favorably predisposed toward exporting. Several studies have investigated the effect of planning and control on exporting, with the majority reporting strong positive correlations with export performance (Barret \& Wilkinson, 1986; DaRocha, Christensen, \& DaCunha, 1990; Suarez \& Vera, 2005). Unfortunately, these two constructs were neither fully operationalized, nor was their specific association with exporting explained. Few export studies have focused on the organizing and leading functions, and no significant association with exporting has been identified (Holzmuller \& Kasper, 1991). Clearly, the export commitment is crucial in business initiation, development and performance and it would be particularly valuable to assess its role in influencing exporting. 


\section{ACKNOWLEDGEMENTS}

Hind El Makrini would like to thank Adrien Bonache, lecturer and researcher at the IAE of Dijon. When he was a lecturer and researcher at Clermont University where Hind El Makirini was a phd student, Adrien Bonache helped her understand the principles of meta-analyses and recommended her to refer to his coauthored article "Bonache, A., Moris, K., Maurice, J. (2012), Participation budgétaire et performance managériale: lien non significatif et contingences, Comptabilité - Contrôle - Audit, 18 (2), pp. 125-184)".

\section{AUTHOR INFORMATION}

Anissa Chaibi is an assistant researcher at IPAG Business School, France. Her research focuses on statistics and econometrics applied to economics and finance. She has published her recent articles in referred journals such as Economic Modelling, Energy Policy and Energy Economics. E-mail: anissa.chaibi@ipag.fr

Hind EI Makrini is an assistant Professor ESDES - Université Catholique de Lyon, France. Her research focuses on strategic management and international marketing. She participated at several conferences and published academic articles in refereed journals (Business Process Management Journal, Journal of Strategic Marketing). E-mail: hind.roche@etu.udamail.fr

\section{REFERENCES}

Aaby, \& Slater. (1989). Management Influences on Export Performance: A Review of the Empirical Literature 1978-88. [Article]. International Marketing Review, 6(4), 7.

Akyol, \& Akehurst. (2003). An Investigation of Export Performance Variations Related to Corporate Export Market Orientation. European Business Review, 15(1), 5-19.

Balabanis, Theodosiou, \& Katsikea. (2004). Export Marketing: Developments and a Research Agenda. International Marketing Review, 21 ((4/5)), 353- 377

Barney, J. B. (1991), Firm resources and sustainable competitive advantage, Journal of Management, 17, pp. 99-120.

Barret, \& Wilkinson. (1986). Internationlaisation Behaviour :Management Characteristics of Australian Manufacturing Firms by Level of International Development. in Research in International Marketing, P.W. Turnbull and S.J Paliwodi, Eds. Beckenham, Kent: Croom Helm.

Becker. (1994). Combining signifi cance levels: In The handbook of research syntheis (Eds, Cooper, H., Hedges, L.V.). New York : Russel Sage Foundation.

Bijmolt, \& Zwart. (1994). The Impact of Internal Factors on the Export Success of Dutch Small and Medium sized firms,. Journal of Small Business Management, 69-82.

Blesa, \&'s, R. (2008). The Influence of Marketing Capabilities on Economic International Performance. International Marketing Review, 25(6), 651-673. .

Bonache, Maurice, \& Moris. (2012). Participation budgétaire et performance managériale : lien non significatif et contingences, Comptabilité Contrôle Audit, 18 (2), pp. 125-184.

Bonoma, \& Clark, (1988), Marketing Performance Assessment, Boston, Massachusetts: Harvard Business School Press

Bourantas, \& Halikias. (1991). Discriminating variables between systematic and non-systematic exporting manufacturing firms in Greece. Journal of Global Marketing, 4(2), 21-38.

Brodrechtova. (2008). Determinants of export marketing strategies of forest products companies in the context of transition - The case of Slovakia. Forest Policy and Economics, 10(7), 450-459.

Cadogan, Cui, \& Yeung Li. (2003). Export Market oriented Behavior and Export Performance: The Moderating Roles of Competitive Intensity and Technological Turbulence. International Marketing Review, 20(5), 493513.

Cavusgil, \& Zou. (1994). Marketing Strategy-Performance Relationship: An Investigation of the Empirical Link in Export Market Ventures. [Article]. Journal of Marketing, 58(1), 1-21.

Chetty, \& Hamilton. (1993). Firm-level determinants of export performance: A meta-analysis. International Marketing Review, 10(3), 26-34.

Conover (1980). Practical nonparametric statistics, 2nd ed. Wiley, New York. 
Cucherat, Boissel, \& Leizorovicz. (1997). Méta-analyse des essais thérapeutiques: Paris : Masson.

DaRocha, Christensen, \& DaCunha. (1990). Aggressive and passive exporters: a study in the brazilian furniture industry. Int Mark Rev, 7(5), 6-15.

Das. (1994). Successful and Unsuccessful Exporters from Developing Countries. European Journal of Marketing Intelligence \& Planning, 28(12), 19-33.

DeLuz. (1993). Relationship Between Export Strategy Variables and Export Performance for Brazil Based Manufacturers. Journal of Global Marketing, 7(1), 87.

Dhanaraj, \& Beamish. (2003). A resource-based approach to the study of export performance. Journal of Small Business Management, 41(3), 242-261.

Dominguez, \& Sequeira. (1993). Determinants of LCD Exporter's Performance: A Cross National Study. Journal of International Business Studies, 1, 19-40.

Evangelista. (1994). Export Performance and its Determinants: Some Empirical Evidence from Aus-tralian Manufacturing Firms. Advances in International Marketing, 207-229.

Fisher (1932). Statistical Methods for Research Workers, 4th ed. Oliver and Boyd, Edinburgh.

Francis, \& Collins-Dodd. (2004). Impact of Export Promotion Programs on Firm Competencies, Strategies and Performance, The case of Canadian high-technology SMEs. International Marketing Review, 21(4/5), 474495.

Greenland, S., \& O'Rourke, K. (2001). On the bias produced by quality scores in meta-analysis, and a hierarchical view of proposed solutions. Biostatistics, 2(4), 463-471.

Haghighi, \& Ataei. (2010). Evaluation of access food exporting companies to information of export market and its effect on export decision process. Iranian Journal of Modiriat Bazargani, 2(4), 19-26.

Hedges, \& Olkin. (1985). Statistical methods for meta-analysis: Orlando : Academic Press.

Holzmuller, \& Kasper. (1991). On the theory of export performance: personal and organizational determinants of export trade activities observed in small and medium-sized firms. Manage Int Rev, 31, 45-70.

Holzmüller, \& Stöttinger. (1996). "Structural Modeling of Success Factors in Exporting: Cross-Validation and Further Development of and Export Performance Model". Journal of International Marketing, 4(2), 29-55.

Julian, \& Nhat (2007). The internet and export marketing performance: the empirical link in export market ventures. Asia Pac. J. Mark. Logis., 19(2), 27-144.

Katsikeas, Leonidou, \& Morgan. (2000), Firm level Export Performance Assessment:

Review, Evaluation, and Development, Journal of the Academy of Marketing Science, 28(4), 493-511.

Köksal. (2008). How Export Marketing Research Affects Company Export Performance:Evidence from Turkish companies. Marketing Intelligence \& Planning, 6(4), 416-430.

Koziol \& Perlman (1978). Combining independent non-central chi-square tests, Journal of the American Statistical Association, 73, 753-763.

Kumcu, Harcar, \& Kumcu (1995). Managerial perceptions of the adequacy of export incentive programs. Implications for export-led economic development policy. Journal of Business Research Policy, 32(3), 163-174.

Lages, \& Montgomery. (2004). Export Performance as an Antecedent of Export Commitment and Marketing Strategy Adaptation. Evidence from Small and Medium-sized Exporters. European Journal of Marketing, 38(9-10), 1186-1214.

Lages, \& Montgomery. (2005). The Relationship between Export Assistance and Performance Improvement in Portuguese Export Ventures: An Empirical Test Of the Mediating Role of Pricing Strategy Adaptation. European Journal of Marketing, 39(7/8), 755-784.

Lee, \& Griffith. (2004). The marketing strategy-performance relationship in an export-driven developing economy. International Marketing Review, 21(3), 321-334.

Leonidou, \& Katsikeas. (1996). The export development process: an integrative review of empirical models. [Article]. Journal of International Business Studies, 27(3), 517-551.

Leonidou, Katsikeas, \& Samiee. (2002). Marketing Strategy determinates of export performance: a meta-analysis. Journal of Business research, 55(1), 517-567.

Lim, Sharkey, \& Heinrichs. (2006). Strategic Impact of New Product Development on Export Involvement. European Journal of Marketing, 40(1/2), 44-60.

Louter, Ouwerker, \& Bakker. (1991). An Inquiry into Successful Exporting European Journal of Marketing, 6, 723. 
Madsen. (1989). Successful Export Marketing Management: Some Empirical Evidence. [Article]. International Marketing Review, 6(4), 41.

Madsen. (1994). A contingency approach to export performance research In Cavusgil, S.T. and Axinn, C.N. (Eds). Advances in International Marketing, 6, 25-42.

Matthyssens, \& Pauwels. (1996). Assessing Export Performance Measurement. New York: JAI Press.

Morgan, Kaleka, \& Katsikeas. (2004). Antecedents of export venture performance: A theoretical model and empirical assessment. Journal of Marketing, 68(1), 90-108.

Navarro, Losada, Ruzo, \& Díez. (2010). Implications of perceived competitive advantages, adaptation of marketing tactics and export commitment on export performance. [Article]. Journal of World Business, 45(1), 49-58. doi: 10.1016/j.jwb.2009.04.004

Nazar, \& Saleem. (2009). Firm level determinates of export performance. J. Int. Bus. Econom. Res, 8(2), 105-112.

Newbert. (2007), Empirical research on the resource-based view of the firm: an assessment and suggestions for future research, Strategic Management Journal, 28, 121-146

O'Cass, A., \& Julian, C. (2003). Examining firm and environmental influences on export marketing mix strategy and export performance of Australian exporters. [Article]. European Journal of Marketing, 37(3/4), 366-384.

O'Cass, \& Weerawardena. (2009). Examining the role ofInternational Entrepreneurship, Innovation and International Market Performance in SME Internationalization. European Journal of Marketing, 43(11/12), $1325-1348$.

O'Sullivan, \& Butler. (2009). Market Orientation and Enterprise Policy. European Journal of Marketing, 43(11/12), 1349-1364.

Papadopoulos, \& Martin, M. (2010). Toward a model of the relationship between internationalization and export performance. Int. Bus. Rev, 19, 388-406.

Pearson (1904). Report on certain enteric fever inoculation statistics. British Medical Journal, 3, 1243-1246.

Racela, \& Chaikittisilpa. (2007). Market Orientation, International Business Relationships and Perceived Export Performance. International Marketing Review, 24(2), 144-163.

Rosenthal (1978). Combining results of independent studies. Psychological Bulletin, 85, 185-193.

Samiee, \& Walters. (1990). Influence of firm size on export planning and performance. Journal of Business Research, 20, 235-248.

Shamsuddoha. (2004). Antecedents of firm export performance: The role of export promotion programs. $\mathrm{PhD}$ Dissertation, Queensland University, Australia.

Shamsuddoha, \& (2006). Mediated Effects of Export Promotion Programmes on Firm Export Performance. Asia Pacific Journal of Marketing and Logistics, 18(2), 93-110.

Singer, \& Czinkota. (1994). Factors associated with effective use of export assistance. Journal of International Marketing, 2, 53-71.

Slavin. (1995). Best evidence synthesis : An intelligent alternative to meta-analysis. Journal of Clinical Epidemiology 48(1), 9-18.

Sousa. (2004). Export performance measurement: An evaluation of the empirical research in the literature. Academy of Marketing Science Review, 9, 1-22.

Sousa, Martínez-López, \& Coelho. (2008). The determinants of export performance: A review of the research in the literature between 1998 and 2005. [Article]. International Journal of Management Reviews, 10(4), 343374. doi: $10.1111 / \mathrm{j} .1468-2370.2008 .00232 . x$

Sriram, \& Manu. (1995). Country-of-destination and export marketing strategy: a study of US exporters. Journal of Global Marketing, 8(3-4), 171-190.

Stoian, Rialp, \& Rialp. (2011). Export performance under the microscope: A glance through Spanish lenses. International Business Review, 20, 117-135.

Styles. (1998). Export Performance Measures in Australia and the United Kingdom. Journal of International

Marketing, 6 (3), 12-36.

Suarez, \& Vera. (2005). SMES internationalization: firms and managerial factors. Int. J. Entrep. Behav. Res., 11(4), 258- 279.

Tippett (1931). The Methods of Statistics. Williams \& Norgate Ltd., London.

Ural. (2009). The Effects of Relationship Quality on Export Performance A Classification of Small and MediumSized Turkish Exporting Firms Operating in Single Export-Market Ventures. European Journal of Marketing, 43(1/2), 139-168.

White, Griffith, \& Ryans. (1998). Measuring Export Performance in the Service Industries. International Market 
Review, 188-204.

Wilkinson, \& Brouthers. (2006). Trade promotion and SME export performance. International Business Review, 15, 233-252.

Yin. (2009). Case study research: Design and methods (Vol. 4): Sage Publications, Thousand Oak, California.

Zou, \& Stan. (1998). The determinants of export performance: a review of the empirical literature between 1987 and 1997. J. Int. Mark. Rev., 15(5), 333-350.

Zou, Taylor, \& Osland. (1998). The EXPERF Scale: A cross-national generalized export performance measure. Journal of international Marketing, 6(3), 37-58. 